\title{
Menentukan Karyawan yang Layak Dirumahkan di Masa Pandemi COVID-19
}

\author{
Narti \\ STMIK Nusa Mandiri \\ narti.nrx@nusamandiri.ac.id
}

\begin{abstract}
Abstrak - Ditahun 2019 merupakan tahun kesedihan seluruh penduduk di bumi, karena banyak Negara yang terjangkit virus Corona (COVID-19) termasuk Negara Indonesia. Sampai dengan tahun 2020, COVID-19 di Indonesia belum juga hilang. Dengan adanya virus Corona ini menyebabkan adanya pembatasan sosial berskala besar (PSBB) yang mengharuskan penduduk untuk tidak melakukan aktivitas diluar rumah. Banyak perusahaan yang mengalami penurunan pendapatan akibat adanya virus tersebut sehingga berdampak adanya pengurangan tenaga kerja, seperti pada salah satu perusahaan yang menjadi bahan observasi penelitian ini. Sebuah perusahaan akan melakukan pengurangan karyawan namun mengalami kesulitan dalam memilih karyawan yang layak dirumahkan. Penelitian ini dilatarbelakangi oleh adanya alasan tersebut, sehingga penulis memutuskan menggunakan metode SAW (Simple Addictive Weighting) untuk membantu mengambil keputusan memilih karyawan yang layak dirumahkan dengan kriteria kedisiplinan, pengetahuan, sikap, kemampuan, penampilan dengan jumlah alternatif 42 orang karyawan. Dalam penelitian ini penulis menentukan alternatif berdasarkan pencarian sampling yang dilakukan menggunakan rumus slovin. Penggunaan metode SAW ini berkonsep dasar menjumlahkan penilaian kinerja pada semua alternatif di semua atribut dengan bobot.
\end{abstract}

Kata Kunci : SPK, SAW, Karyawan dirumahkan, COVID-19

\begin{abstract}
- 2019 is a year of sadness for all people on earth, because many countries have contracted the Corona virus (COVID-19), including Indonesia. Until 2020, COVID-19 in Indonesia has not disappeared. With the Corona virus this has led to large-scale social savings (PSBB) which requires residents not to carry out activities outside the home. Many companies have experienced a decline in income due to the virus, which has caused a change in workforce, such as one company that was the research object of this study. A company will be successful at performing employees but have difficulty selecting employees who deserve to be laid off. This research is motivated by these reasons, so the authors decided to use the SAW (Simple Addictive Weighting) method to help make decisions about choosing employees who deserve to be laid off with assessment criteria, knowledge, attitudes, abilities, discipline with an alternative number of 42 employees. In this study, the authors determine based on the order of sampling carried out using the Slovin formula. The use of the SAW method is the basic concept of adding up the performance appraisals on all alternatives in all attributes with weights.

Keywords: SPK, SAW, Employee sent home, COVID-19
\end{abstract}

\section{PENDAHULUAN}

Negara Indonesia termasuk Negara yang ikut terjangkit wabah virus Corona (COVID-19). Akhir tahun 2019 warga dunia dihebohkan dengan adanya virus Corona yang berasal dari Negara Cina, hingga akhir tahun 2020 virus Corona belum juga menghilang, Dengan adanya virus Corona di Negara Indonesia, menyebabkan adanya pembatasan sosial berskala besar (PSBB) yang mewajibkan penduduk Indonesia terutama yang berada dalam wilayah zona merah untuk tidak melakukan aktivitas diluar rumah.

Dengan adanya virus tersebut berdampak pada perusahaan yang mengalami penurunan pendapatan sehingga menyebabkan adanya pengurangan tenaga kerja, seperti pada salah satu perusahaan yang menjadi bahan observasi penelitian ini. Sebuah perusahaan akan melakukan pengurangan karyawan namun mengalami kesulitan dalam memilih karyawan yang layak dirumahkan.
Penelitian ini didasari dengan adanya alasan tersebut, sehingga penulis memutuskan menggunakan metode SAW (Simple Addictive Weighting) untuk membantu mengambil keputusan memilih karyawan yang layak dirumahkan dengan kriteria kedisiplinan, pengetahuan, sikap, kemampuan, penampilan dengan jumlah alternatif 42 orang karyawan. Dalam penelitian ini penulis menentukan alternatif berdasarkan pencarian sampling yang dilakukan menggunakan rumus slovin. Penggunaan metode SAW ini berkonsep dasar menjumlahkan penilaian kinerja pada semua alternatif di semua atribut dengan bobot.

Metode simple additive weighting (SAW) adalah metode sistem pendukung keputusan yang bisa di gunakan perusahaan untuk mengambil sebuah keputusan. Konsep dasar metode SAW (Simple Additive Weighting) adalah mencari penjumlahan terbobot dari rating kinerja pada setiap alternatif pada semua atribut. (Pamungkas \& Kusnadi, 2019) 


\section{Sistem Pendukung Keputusan}

Sistem merupakan kumpulan elemen yang saling berkolerasi satu dengan yang lainnya untuk mencapai tujuan tertentu. Sedangkan Keputusan sebagai kegiatan memilih suatu strategi atau tindakan dalam pemecahan masalah tersebut. (Fitriyani, Handayani, \& Widanengsih, 2020)

Menurut Bonczek, dkk sistem pendukung keputusan sebagai sistem berbasis computer yang terdiri dari sistem bahasa system pengetahuan, dan sistem pemrosesan masalah.Dan ketiga komponen tersebut saling berinteraksi. (Nofriansyah \& Dick, 2015)

\section{Metode Simple Additive Weighting (SAW)}

Metode Simple Additive Weighting (SAW) sering juga dikenal istilah metode penjumlahan terbobot. Konsep dasar metode Simple Additive Weighting (SAW) adalah mencari penjumlahan terbobot dari rating kinerja pada setiap alternative pada semua kriteria. (Nurlela, Akmaludin, Hadianti, \& Yusuf, 2019) Metode ini merupakan metode yang paling dikenal dan paling banyak digunakan orang dalam menghadapi situasi MADM (multiple attribute decision making). Metode ini. Mengharuskan pembuat keputusan menentukan bobot bagi setiap atribut. Skor total untuk sebuah alternatif diperoleh dengan menjumlahkan seluruh hasil perkalian antara rating (yang dapat dibandingkan lintas atribut) dan bobot tiap atribut. Rating tiap atribut haruslah bebas dimensi yang artinya telah melewati proses normalisasi sebelumnya. (Nurma'ruf \& Herdi, 2019)

SAW merupakan proses dalam pengambilan keputusan dengan menggunakan perbandingan berpasangan (Pairwise Comparisons) untuk menjelaskan faktor evaluasi dan faktor bobot dalam kondisi multi faktor. Dengan demikian SAW digunakan manakala keputusan yang diambil melibatkan banyak faktor, dimana pengambil keputusan mengalami kesulitan dalam membuat bobot setiap faktor tersebut. (Wahyudi, Suheri, \& Nurhadian, 2015)

Konsep dasar metode SAW adalah mencari penjumlahan terbobot dari rating kinerja pada setiap alternatif pada semua atribut. (Rizkandari, Saptono, \& Wiharto, 2014)

Rumus untuk melakukan normalisasi tersebut adalah :

$$
r i j \begin{cases}\frac{X i j}{\operatorname{Max} X i j} & \text { jika } \mathrm{j} \text { adalah atribut keuntungan (benefit) } \\ \frac{\operatorname{Min} X i j}{i} & \text { jika } \mathrm{j} \text { adalah atribut biaya (cost) }\end{cases}
$$

Keterangan :

Rij = Nilai rating kinerja normalisasi
$X_{i j}=$ Nilai atribut yang dimiliki dari setiap kriteria

Max = Nilai terbesar dari setiap kriteria

Benefit $=$ Nilai terbesar adalah terbaik

Cost = Nilai terkecil adalah terbaik

Dimana rij adalah rating kinerja ternomalisasi dari alternatif Ai pada atribut $\mathrm{Cj}: \mathrm{j}=1,2, \ldots, \mathrm{m}$ dan $j=1,2, \ldots, n$

$V i=\sum_{j=1}^{n} w j r i j$

Keterangan :

$\mathrm{Vi}=$ Nilai akhir alternatif

$\mathrm{Wj}=$ Bobot yang telah ditentukan

Rij = Normalisasi matriks

Nilai Vi yang lebih besar mengindikasikan bahwa alternatif Ai lebih terpilih. Dengan kata lain antara bobot kriteria (w) dikalikan dengan semua nilai tiap karyawan ( $r$ ) untuk tiap kriteria dan dijumlahkan. (Utsalina \& Khamidah, 2017)

\section{Wabah dan Corona Virus}

Wabah istilah umumnya untuk menyebut kejadian tersebarnya penyakit pada daerah yang luas dan pada banyak orang, maupun untuk menyebar penyakit yang menyebar tersebut. (Tamher \& Noorkasiani, 2008)

COVID-19 singkatan dari Coronavirus Disease 2019. Sedangkan Coronavirus atau coronaviridae adalah nama family atau keluarga besar virus yang dapat menyebabkan penyakit pada manusia dan binatang. Coronavirus memiliki ratusan anggota keluarga. Tujuh diantara diketahui dapt menyerang manusia. Pada manusia, umumnya virus ini menyebabkan infeksi saluran pernapasan dari ringan hingga berat. Infeksi saluran penapasan berat disebabkan oleh tiga anggota coronavirus, yaitu SARSCov (Severe Acute Respiratory Syndrome Coronavirus) yang mewabah ditahus 20022004, yang kedua yaitu MERS-CoV (Middle East Respiratory Syndrome Related Coronavirus) yang mewabah ditahun 20122013, dan yang terbaru SARS-CoV-2 (Servere Acute Respiratory Syndrom Coronavirus 2) yang pertam kali ditemukan pada November 2019 dan dideklarasikan sebagai pandemi oleh WHO di Maret 2020. SARS-CoV-2 inilah yang menyebabkan penyakit yang disebut dengan COVID-19 (Coronavirus Disease 2019).(Shihab, 2020)

\section{METODOLOGI PENELITIAN}

Dalam penelitian ini mengambil 42 jumlah karyawan yang akan di ambil nilai kriterianya dan akan dihitung menggunakan metode SAW dibawah akan dijabarkan langkah-langkah perhitungannya. 
Table 1. Daftar Nama Karyawan

\begin{tabular}{llll}
\hline No. & Nama & No. & Nama \\
\hline 1 & Ari Kurniawan & 22 & Melda \\
2 & Rozaki & 23 & Jajang Sunarya \\
3 & Pahlevi & 24 & Sunardi \\
4 & Nina Wati & 25 & Ita Malita \\
5 & Linda Sari & 26 & Sifa Fauzia \\
6 & Eka Yulianti & 27 & Santi \\
7 & Marisa & 28 & Susanti \\
8 & Budiawan Salim & 29 & Alika Narullah \\
9 & Andre Mulia & 30 & Nasrul \\
10 & Kosasih & 31 & Doni Setiawan \\
11 & Andri Maulana & 32 & Dika Maulana \\
12 & Ridwan & 33 & Sanwani \\
13 & Salim & 34 & Nur Hasanah \\
14 & Khodijah & 35 & Nani Kusti \\
15 & Salsabila & 36 & Bani Salim \\
16 & Ika Setiana & 37 & Kukung Pangestu \\
17 & Melita & 38 & Bayu Aji \\
18 & Rosdiana & 39 & Aji Bangun \\
19 & Malik Saleh & 40 & Septiani \\
20 & Ridwan Munawan & 41 & Kudsiawati \\
21 & Astani & 42 & Denis Ade \\
\hline
\end{tabular}

A. Nilai Bobot Kriteria

Bobot prefensi yang diberikan sebagai berikut :

\begin{tabular}{lc}
\multicolumn{2}{c}{ Tabel 2. Bobot Kriteria } \\
\hline \multicolumn{1}{c}{ Kriteria } & Bobot \\
\hline Kedisiplinan & $20 \%$ \\
Pengetahuan & $20 \%$ \\
Sikap & $20 \%$ \\
Kemampuan & $30 \%$ \\
Penampilan & $10 \%$ \\
\hline
\end{tabular}

B. Nilai Kriteria Pada Setiap Alternatif Berdasarkan data dari penilai maka disusun tabel kecocokan kriteria pada setiap alternatif, yaitu sebagai berikut :

Tabel 3. Kecocokan Kriteria Pada Setiap Alternatif

\begin{tabular}{lllllll}
\hline \multirow{2}{*}{ NO } & \multirow{2}{*}{ NAMA } & \multicolumn{3}{l}{ KRITERIA } \\
\cline { 3 - 7 } & & C1 & C2 & C3 & C4 & C5 \\
\hline $\mathbf{1}$ & Ari Kurniawan & 4 & 5 & 5 & 5 & 5 \\
$\mathbf{2}$ & Rozaki & 5 & 5 & 5 & 5 & 3 \\
$\mathbf{3}$ & Pahlevi & 5 & 5 & 5 & 5 & 3 \\
$\mathbf{4}$ & Nina Wati & 5 & 5 & 5 & 5 & 3 \\
$\mathbf{5}$ & Linda Sari & 5 & 5 & 4 & 5 & 4 \\
$\mathbf{6}$ & Eka Yulianti & 5 & 5 & 4 & 5 & 3 \\
$\mathbf{7}$ & Marisa & 5 & 5 & 5 & 5 & 3 \\
$\mathbf{8}$ & Budiawan Salim & 5 & 5 & 5 & 5 & 4 \\
$\mathbf{9}$ & Andre Mulia & 5 & 5 & 4 & 5 & 2 \\
$\mathbf{1 0}$ & Kosasih & 5 & 5 & 5 & 5 & 2 \\
$\ldots$ & $\ldots$ & $\ldots$ & $\ldots$ & $\ldots$ & $\ldots$ & $\ldots$ \\
$\mathbf{4 2}$ & Denis Ade & 5 & 5 & 5 & 5 & 4 \\
\hline
\end{tabular}

C. Membuat Matriks Keputusan Matriks keputusannya adalah sebagai berikut :

$$
\left[\begin{array}{ccccc}
4 & 5 & 5 & 5 & 5 \\
5 & 5 & 5 & 5 & 3 \\
5 & 5 & 5 & 5 & 3 \\
5 & 5 & 5 & 5 & 3 \\
5 & 5 & 4 & 5 & 4 \\
5 & 5 & 4 & 5 & 3 \\
5 & 5 & 5 & 5 & 3 \\
5 & 5 & 5 & 5 & 4 \\
5 & 5 & 4 & 5 & 2 \\
5 & 5 & 5 & 5 & 2 \\
\cdots & \cdots & \cdots & \cdots & \cdots \\
5 & 5 & 5 & 5 & 4 \\
& & & &
\end{array}\right]
$$

D. Normalisasi Matriks

Membuat normalisasi matriks keputusan ke suatu skala yang dapat diperbandingkan dengan semua alternative yang ada. Menentukan nilai R dengan Rumus Berikut :

$$
\mathrm{Rij}=\frac{\mathrm{Xij} \ldots \ldots \ldots \ldots}{\operatorname{Max} \mathrm{Xij}}
$$

Keterangan :

$\mathrm{Rij}=$ Nilai rating kinerja normalisasi

$\mathrm{Xij}=$ Nilai atribut yang dimiliki dari setiap kriteria

Max $=$ Nilai terbesar dari setiap kriteria

Tabel 4. Untuk kriteria Kedisiplinan

\begin{tabular}{ll}
\hline Nama & $\mathbf{R}$ \\
\hline Ari Kurniawan & 0.8 \\
Rozaki & 1 \\
Pahlevi & 1 \\
Nina Wati & 1 \\
Linda Sari & 1 \\
Eka Yulianti & 1 \\
Marisa & 1 \\
Budiawan Salim & 1 \\
Andre Mulia & 1 \\
Kosasih & 1 \\
... & $\ldots$ \\
Denis Ade & 1 \\
\hline
\end{tabular}

Tabel 5. Untuk kriteria Pengetahuan

\begin{tabular}{lc}
\hline Nama & R \\
\hline Ari Kurniawan & 1 \\
Rozaki & 1 \\
Pahlevi & 1 \\
Nina Wati & 1 \\
\hline
\end{tabular}




\begin{tabular}{ll}
\hline Linda Sari & 1 \\
Eka Yulianti & 1 \\
Marisa & 1 \\
Budiawan Salim & 1 \\
Andre Mulia & 1 \\
Kosasih & 1 \\
$\ldots$ & $\ldots$ \\
Denis Ade & 1 \\
\hline
\end{tabular}

\begin{tabular}{lc}
\hline Budiawan Salim & 0.8 \\
Andre Mulia & 0.4 \\
Kosasih & 0.4 \\
$\ldots$ & $\ldots$ \\
Denis Ade & 0.8 \\
\hline
\end{tabular}

Tabel 6. Untuk kriteria Sikap

\begin{tabular}{lc}
\hline Nama & $\mathbf{R}$ \\
\hline Ari Kurniawan & 1 \\
Rozaki & 1 \\
Pahlevi & 1 \\
Nina Wati & 1 \\
Linda Sari & 1 \\
Eka Yulianti & 0.8 \\
Marisa & 1 \\
Budiawan Salim & 1 \\
Andre Mulia & 0.8 \\
Kosasih & 1 \\
... & $\ldots$ \\
Denis Ade & 1 \\
\hline
\end{tabular}

Tabel 7. Untuk kriteria Kemampuan

\begin{tabular}{ll}
\hline Nama & $\mathbf{R}$ \\
\hline Ari Kurniawan & 1 \\
Rozaki & 1 \\
Pahlevi & 1 \\
Nina Wati & 1 \\
Linda Sari & 1 \\
Eka Yulianti & 1 \\
Marisa & 1 \\
Budiawan Salim & 1 \\
Andre Mulia & 1 \\
Kosasih & 1 \\
... & $\ldots$ \\
Denis Ade & 1 \\
\hline
\end{tabular}

Tabel 8. Untuk kriteria Penampilan

\begin{tabular}{lc}
\hline Nama & $\mathbf{R}$ \\
\hline Ari Kurniawan & 1 \\
Rozaki & 0.6 \\
Pahlevi & 0.6 \\
Nina Wati & 0.6 \\
Linda Sari & 0.8 \\
Eka Yulianti & 0.6 \\
Marisa & 0.6 \\
\hline
\end{tabular}

E. Menentukan Peringkat

Menentukan nilai $\mathrm{V}_{1}$ sampai dengan $\mathrm{V}_{42}$ adalah sebagai berikut :

\begin{tabular}{ll}
\multicolumn{2}{l}{ Tabel 9. Menentukan peringkat } \\
\hline Nama & $\mathbf{V}$ \\
\hline Ari Kurniawan & 0.96 \\
Rozaki & 0.96 \\
Pahlevi & 0.96 \\
Nina Wati & 0.96 \\
Linda Sari & 0.98 \\
Eka Yulianti & 0.92 \\
Marisa & 0.98 \\
Budiawan Salim & 0.98 \\
Andre Mulia & 0.9 \\
Kosasih & 0.95 \\
$\ldots$ & $\ldots$ \\
Denis Ade & 0.98 \\
\hline
\end{tabular}

Tabel 10. Hasil penentuan peringkat

\begin{tabular}{clcc}
\hline NO & NAMA & PERSENTASE & PERINGKAT \\
\hline 1 & Ari Kurniawan & $96 \%$ & 12 \\
2 & Rozaki & $96 \%$ & 13 \\
3 & Pahlevi & $96 \%$ & 14 \\
4 & Nina Wati & $96 \%$ & 15 \\
5 & Linda Sari & $98 \%$ & 5 \\
\hline
\end{tabular}

Dari perhitungan nilai $\mathrm{R}$ diatas di dapat matriks $\mathrm{R}$ sebagai berikut :

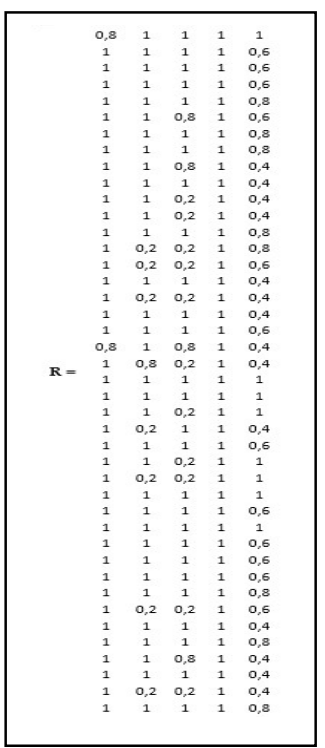




\begin{tabular}{|c|c|c|c|}
\hline 6 & Eka Yulianti & $92 \%$ & 27 \\
\hline 7 & Marisa & $98 \%$ & 6 \\
\hline 8 & Budiawan Salim & $98 \%$ & 7 \\
\hline 9 & Andre Mulia & $90 \%$ & 28 \\
\hline 10 & Kosasih & $94 \%$ & 22 \\
\hline 11 & Andri Maulana & $78 \%$ & 33 \\
\hline 12 & Ridwan & $78 \%$ & 34 \\
\hline 13 & Salim & $98 \%$ & 8 \\
\hline 14 & Khodijah & $66 \%$ & 38 \\
\hline 15 & Salsabila & $64 \%$ & 39 \\
\hline 16 & Ika Setiana & $94 \%$ & 23 \\
\hline 17 & Melita & $62 \%$ & 41 \\
\hline 18 & Rosdiana & $94 \%$ & 24 \\
\hline 19 & Malik Saleh & $96 \%$ & 16 \\
\hline 20 & $\begin{array}{l}\text { Ridwan } \\
\text { Munawan }\end{array}$ & $86 \%$ & 30 \\
\hline 21 & Astani & $74 \%$ & 36 \\
\hline 22 & Melda & $100 \%$ & 1 \\
\hline 23 & Jajang Sunarya & $100 \%$ & 2 \\
\hline 24 & Sunardi & $84 \%$ & 31 \\
\hline 25 & Ita Malita & $78 \%$ & 35 \\
\hline 26 & Sifa Fauzia & $96 \%$ & 17 \\
\hline 27 & Santi & $84 \%$ & 32 \\
\hline 28 & Susanti & $68 \%$ & 37 \\
\hline 29 & Alika Narullah & $100 \%$ & 3 \\
\hline 30 & Nasrul & $96 \%$ & 18 \\
\hline 31 & Doni Setiawan & $100 \%$ & 4 \\
\hline 32 & Dika Maulana & $96 \%$ & 19 \\
\hline 33 & Sanwani & $96 \%$ & 20 \\
\hline 34 & Nur Hasanah & $96 \%$ & 21 \\
\hline 35 & Nani Kusti & $98 \%$ & 9 \\
\hline 36 & Bani Salim & $64 \%$ & 40 \\
\hline 37 & $\begin{array}{l}\text { Kukung } \\
\text { Pangestu }\end{array}$ & $94 \%$ & 25 \\
\hline 38 & Bayu Aji & $98 \%$ & 10 \\
\hline 39 & Aji Bangun & $90 \%$ & 29 \\
\hline 40 & Septiani & $94 \%$ & 26 \\
\hline 41 & Kudsiawati & $62 \%$ & 42 \\
\hline 42 & Denis Ade & $98 \%$ & 11 \\
\hline
\end{tabular}

sampel dari 72 karyawan. 42 karyawan yang termasuk dalam calon karyawan yang akan dirumahkan telah diolah menggunakan menggunakan metode SAW. Berikut merupakan table penentuan peringkat yang nantinya akan diambil 12 orang karyawan yang akan dirumahkan.

Tabel 11. Urutan nilai dari terbesar sampai terkecil

\begin{tabular}{|c|c|c|}
\hline NAMA & PERSENTASE & PERINGKAT \\
\hline Melda & $100 \%$ & 1 \\
\hline Jajang Sunarya & $100 \%$ & 2 \\
\hline Alika Narullah & $100 \%$ & 3 \\
\hline Doni Setiawan & $100 \%$ & 4 \\
\hline Linda Sari & $98 \%$ & 5 \\
\hline Marisa & $98 \%$ & 6 \\
\hline Budiawan Salim & $98 \%$ & 7 \\
\hline Salim & $98 \%$ & 8 \\
\hline Nani Kusti & $98 \%$ & 9 \\
\hline Bayu Aji & $98 \%$ & 10 \\
\hline Denis Ade & $98 \%$ & 11 \\
\hline Ari Kurniawan & $96 \%$ & 12 \\
\hline Rozaki & $96 \%$ & 13 \\
\hline Pahlevi & $96 \%$ & 14 \\
\hline Nina Wati & $96 \%$ & 15 \\
\hline Malik Saleh & $96 \%$ & 16 \\
\hline Sifa Fauzia & $96 \%$ & 17 \\
\hline Nasrul & $96 \%$ & 18 \\
\hline Dika Maulana & $96 \%$ & 19 \\
\hline Sanwani & $96 \%$ & 20 \\
\hline Nur Hasanah & $96 \%$ & 21 \\
\hline Kosasih & $94 \%$ & 22 \\
\hline Ika Setiana & $94 \%$ & 23 \\
\hline Rosdiana & $94 \%$ & 24 \\
\hline Kukung Pangestu & $94 \%$ & 25 \\
\hline Septiani & $94 \%$ & 26 \\
\hline Eka Yulianti & $92 \%$ & 27 \\
\hline Andre Mulia & $90 \%$ & 28 \\
\hline Aji Bangun & $90 \%$ & 29 \\
\hline Ridwan Munawan & $86 \%$ & 30 \\
\hline Sunardi & $84 \%$ & 31 \\
\hline Santi & $84 \%$ & 32 \\
\hline Andri Maulana & $78 \%$ & 33 \\
\hline Ridwan & $78 \%$ & 34 \\
\hline Ita Malita & $78 \%$ & 35 \\
\hline Astani & $74 \%$ & 36 \\
\hline Susanti & $68 \%$ & 37 \\
\hline
\end{tabular}

III. HASIL DAN PEMBAHASAN

Setelah didapatkan hasil perhitungan penentuan peringkat maka dibuatkan tabel diurutkan berdasarkan nilai persentase terbesar ke nilai persentase terkecil.

Peringkat 1 merupakan peringkat terbaik dan peringkat terbesar merupakan peringkat terburuk.

Dalam penelitian ini penulis mengambil 42 orang 


\begin{tabular}{lll}
\hline Khodijah & $66 \%$ & $\mathbf{3 8}$ \\
Salsabila & $64 \%$ & $\mathbf{3 9}$ \\
Bani Salim & $64 \%$ & $\mathbf{4 0}$ \\
Melita & $62 \%$ & $\mathbf{4 1}$ \\
Kudsiawati & $62 \%$ & $\mathbf{4 2}$ \\
\hline
\end{tabular}

Dari total 72 karyawan hanya 42 orang yang masuk kandidat dirumahkan. Berdasarkan perhitungan dengan metode SAW (Simple Additive Weighting) maka yang layak bertahan tetap bekerja adalah peringkat 1 sampai dengan peringkat 30 . Sedangkan peringkat 31 sampai dengan 42 terpaksa akan di rumahkan. Nama yang termasuk dalam karyawan yang akan di rumahkan adalah Sunardi, Santi, Andri Maulana, Ridwan, Ita Malita, Astani, Susanti, Khodijah, Salsabila, Bani Salim, Melita dan Kudsiawati.

\section{KESIMPULAN}

Berdasarkan penelitian ini, metode SAW mampu membantu dalam menetukan keputusan yang tepat, pada studi kasus ini, yaitu tentang perusahaan yang ingin mencari karyawan yang layak untuk dirumahkan didapatkan 12 orang karyawan yang memiliki performa paling rendah dan dianggap layak untuk dirumahkan berdasarkan hasil penggunaan metode tersebut.

\section{REFERENSI}

dr. N. shihab. (2020). Covid-19: Kupasan Ringkas yang Perlu Anda Ketahui, Pertama., vol. $13 \times 19 \mathrm{~cm}$. Jakarta: Literati.

Fitriyani, A., Handayani, R. I., \& Widanengsih, E. (2020). Sistem Pendukung Keputusan Pemilihan Jurusan Pada SMK YMIK Joglo Jakarta Barat Menggunakan Metode Simple Additive Weigting ( SAW ). JTKSI, 3(1), 11-19. Retrieved from http://ojs.stmikpringsewu.ac.id/index.php/jt ksi/article/view/784/pdf

M. K. Nofriansyah, Dick. (2015) Konsep Data Mining VS Sistem Pendukung Keputusan, 1st ed. Yogyakarta: Cv Budi Utama.

Nurlela, S., Akmaludin, A., Hadianti, S., \& Yusuf, L. (2019). PENYELEKSIAN JURUSAN TERFAVORIT PADA SMK SIRAJUL FALAH DENGAN METODE SAW. Jurnal PILAR Nusa Mandiri, 15(1), 1-6. Retrieved from https://ejournal.nusamandiri.ac.id/index.ph p/pilar/article/view/1/1

Nurma'ruf, D., \& Herdi, T. (2019). SISTEM PENDUKUNG KEPUTUSAN PENGANGKATAN KARYAWAN TETAP MENGGUNAKAN METODE SAW (SIMPLE ADDITIVE WEIGHTING) PADA INDUSTRI BATTERY (AKI). JUSIBI -
(JURNAL SISTEM INFORMASI DAN EBISNIS), 1(5), 167-176. Retrieved from https://jurnal.ikhafi.or.id/index.php/jusibi/ar ticle/view/126/63

Pamungkas, \& Kusnadi. (2019). Sistem Penunjang Keputusan Pemilihan Karyawan Terbaik Menggunakan Metode Simple Additve Weighting (Saw) Pada PT Ringkat Teknologi Muliatama Jakarta. Pamungkas Kusnadi, 5(1), 71-77. Retrieved from https://docplayer.info/134527841-Jurnaljurnal-teknologi-informatika-komputerfakultas-komputer-uniiversitas-m-hthamrin.html

Rizkandari, S. A., Saptono, R., \& Wiharto, W. (2014). Pemanfaatan Metode Simple Additive Weighting ( SAW ) Dalam Penentuan Mahasiswa Berprestasi Tingkat Universitas Sebelas Maret Surakarta. ITSMART: Jurnal Teknologi Dan Informasi, 3(1), 34-40. Retrieved from

https://jurnal.uns.ac.id/itsmart/article/view/ $646 / 1612$

Tamher and Noorkasiani. (2008). Flu Burung: Aspek Klinis dan Epidemiologis, 1st ed. Jakarta: Penerbit salemba Medika.

Tim Visi Media, "Undang-undang No.13 Tahun 2003 Tentang Ketenagakerjaan \& Undang-undang No.21 Tahun 2000 Tentang Serikat Pekerja/ Serikat Buruh," Google buku. [Online]. Available: https://books.google.co.id/books?id=uKMv vLmBXGMC\&printsec $=$ frontcover\&hl=id\&s ource $=g b s$ ge_summary_r\&cad $=0 \# v=$ one page $\& q \& f=$ false. [Accessed: 12-Jun2020].

Utsalina, D. S., \& Khamidah, L. (2017). Sistem Pendukung Keputusan Penentuan Sales Penerima Insentif Menggunakan Metode Simple Additive Weighting (studi kasus: CV Anugerah Berkat Abadi). SMATIKA Jurnal, 7(2), 8-20. Retrieved from http://jurnal.stiki.ac.id/SMATIKA/article/do wnload/152/132

Wahyudi, S., Suheri, H., \& Nurhadian, T. (2015). IMPLEMENTASI SISTEM KEPUTUSAN PENGANGKATAN KARYAWAN TETAP PT. IMANUEL SURYA UTAMA MENGGUNAKAN METODE SAW. Jurnal PROSISKO, 2(1), 34-41. Retrieved from https://www.semanticscholar.org/paper/IM PLEMENTASI-SISTEM-KEPUTUSANPENGANGKATAN-KARYAWANWahyudiSuheri/dbe87499a3d908f39453cc6a16f43 $5 \mathrm{~d} 33 \mathrm{fc} 9 \mathrm{~d} 2 \mathrm{dc}$ 